\title{
ANALISIS KAPASITAS PELAYANAN PUBLIK PEMERINTAHAN DESA STUDI KASUS DI DESA CIBUNTU KECAMATAN CIBITUNG KABUPATEN BEKASI \\ PROPINSI JAWA BARAT \\ Bambang Istianto ; Taufan Maulamin ;
}

bambang.istianto58@gmail.com; taufanm@gmail.com;

\begin{abstract}
A B S T R A K
Tujuan penelitian ini melakukan analisis kapasitas pelayanan publik pada pemerintahan desa melalui studi Kasus di Desa Cibuntu Kecamatan Cibitung Kabupaten Bekasi Propinsi Jawa Barat.Adapun metode penelitian yang digunakan yaitu metode dengan analisis diskriptif kualitatif. Pengumpulan data berdasarkan observasi lapangan dan grounded research serta indepth interview dengan sejumlah key informan. Hasil penelitian ditemukan bahwa kapasitas pelayanan publik pada Pemerintahan Desa masih sangat lemah. Rendahnya kapasitas pelayanan publik tersebut dikarenakan belum efektifnya Organisasi Pemerintahan desa, rendahnya kompetensi sumberdaya manusia atau perangkat desa, belum efektifnya tata kelola keuangan desa dan lemahnya kepemimpinan pemerintahan desa. Berdasarkan hasil penelitian di sarankan perlu dilakukan penguatan efektifitas organisasi pemerintahan desa, peningkatan kompetensi perangkat desa dan seleksi pemilihan Kapala Desa berdasarkan sistem merit, .

Keyword : Kapasitas, Pelayanan publik, pemerintahan desa.

\section{ABSTRACT}

The purpose of the research is to do the analysis of public service capacity at the Village government through the case study in the Cibuntu Village, Cibitung district, Bekasi-Regency in the province of West- Java. The method of research used is the method of qualitative descriptive analysis. The collection of data is based on the field observationand grounded research as well as in-depth interview with a number of key infomants. The research result found is the public service capacity at the village government is still very weak. The low public service capacity is caused by ineffectiveness of village government organization, the low competency of human resouurces of Village apparaturs. The ineffectiveness of Village financial governance and the weakness of Village government leadership. Based on the research result, it is suggested that the Village government organization, the incrased competence of the Village apparaturs be more effective and the selection of Vilage chief election based on meritorious system.
\end{abstract}

Keyword ; Capacity, public service, Village government. 


\section{I.PENDAHULUAN}

Desa dewasa ini menjadi tranding topik setelah kedudukan pemerintahan Desa mendapat penguatan legitimasi melalui Undang Undang Nomor 6 Tahun 2014 Tentang Desa. Meskipun demikian sejak masa Orde baru sampai saat ini kehidupan masyarakat desa masih belum berubah secara signifikan. Artinya di pedesaan masih tetap menghadapi permasalahan kemiskinan. Sesuai data Biro Pusat Statistik (BPS) mencatat jumlah orang miskin di Indonesia 25, 95 juta jiwa. Pada bulan September 2017 jumlah penduduk miskin yang tinggal di pedesaan berjumlah 16,31 juta orang dan pada bulan maret 2018 turun menjadi 15, 81 juta orang. Sesuai data diatas jumlah penduduk miskin di Indonesia yang tinggal pedesaan sebesar $42 \%$ atau jumlahnya 15, 81 juta orang. ( $h t t p s ; / / m . d e t i k, c o m, 17$ Juli 2018 ) artinya jumlah masyarakat miskin berada di pedesaan masih besar yaitu $42 \%$. Karena itu problem utama yang dihadapi pemerintah desa, bagaimana mengatasi kemiskinan. Usaha mengurangi orang miskin di desa pemerintah berupaya meningkatkan kesejahteraan masyarakat melalui program program pembangunan dari pemerintah pusat dan daerah. Oleh karena sifat program program pembangunan yang dilaksanakan di pedesaan "taken for get it" boleh jadi proyek pembangunan tersebut banyak yang tidak tepat sasaran. Untuk itu upaya percepatan pengentasan kemiskinan di pedesaan jalannya terseok seok.

Seperti diketahui perjalanan panjang pemerintahan desa mengalami liku liku yang sebenarnya tragis. Meminjam istilah yang dikemukakan Suryokoco (2010 ) menyatakan bahwa " desa strategis yang bernasib tragis". Dalam catatan Suryo menjelaskan kedudukan pemerintahan desa dari masa kemasa. Pada masa penjajahan atau kolonialisme Hindia Belanda di keluarkan peraturan yang disebut Wet Houddende Decentralisatie in Nederlandsch Indie pada tanggal 23 Juli 1903 yang sering disingkat Decentralisatie Wet 1903 Berdasarkan pasal 128 Indische Staatsregeling ( IS ), desa diberi hak untuk mengatur urusan rumah tangga mereka sendiri , namun dalam pelaksanaanya pemberian otonomi ini cenderung dipakai pihak kolonial untuk mempertahankan posisinya. Pada masa Orde lama, desa diakui sebagai kesatuan masyarakat hukum yang berhak mengatur dan mengurus rumah tangganya sendiri, baik dalam UU No 22 Tahun 1948 tentang Pemerintahan Daerah, UU No 1 Tahun 1957 Tentang Pemerintahan Daerah maupun dalam UU No 18 Tahun 1965 tentang Pokok Pokok Pemerintahan Daerah serta UU NO 19 tahun 1965 tentang Desapraja. Pada masa Orde Baru, desa diatur berdasarkan UU No 5 Tahun 1979 tentang Pemerintah Desa. Dalam undang undang ini Kepala Desa dijadikan kepanjangan tangan pemerintah, sehingga kekuatan desa dihilangkan. Pada masa reformasi, melalui UU No 22 Tahun 1999 dinilai menghidupkan kembali ruh demokrasi di desa dengan di bentuk parlemen di desa. Tapi dengan di keluarkan UU No 32 tahun 2004 Desa kembali dimaknai sebagai saluran administrative kewenangan negara lewat kabupaten/kota.

Pada masa pemerintahan Presiden Joko Widodo desa diatur dengan UU No 6 Tahun 2014 tentang Pemerintahan Desa. Hasil penelitian Nurcholis ( 2016 ) menemukan bahwa pemerintahan desa bentukan UU No 6 tahun 2014 dinilai sebagai " unit pemerintahan palsu" atau " pseudo government". Artinya dengan status desa tersebut tidak memiliki kapasitas menyelenggarakan pemerintahan dan memberikan pelayanan publik sesuai standar pelayanan minimal. Dengan kata lain sebenarnya "tidak ada pelayanan publik" di desa. Untuk merasionalkan pendapatnya Nurcholis menyebutkan terdapat tiga alasan yaitu; pertama, ia adalah organ negara tapi tidak diselenggarakan oleh pejabat birokrasi negara. Kedua, kewenangan, fungsi, dan tugasnya adalah memberikan " public service", melakukan pembangunan untuk menumbuhkan ekonomi rakyat, dan memberikan perlindungan kepada rakyat demi menyejahterakan masyarakat desa tapi kepala desa dan perangkat desanya tidak mempunyai kapasitas untuk itu. Ketiga, sejak 
dibentuk melalui UU No, 5/1979 anggaran utama untuk menyelenggarakan pemerintahan desa tidak berasal dari negara tapi dari gotong royong adat, upah pungut pajak, dan penarikan uang dari rakyat yang minta surat publik ke kantor desa. Karena itu lembaga desa tersebut tidak mempunyai kapasitas menyelenggarakan pemerinthan dan memberikan pelayanan publik sesuai dengan standar pelayanan yang minimal ( SPM ). Penjelasan diatas menggambarkan bahwa penyelenggaraan pemerintahan desa sampai saat ini belum mampu menumbuhkan kapasitas pemerintahan desa dalam menyelenggarakan pelayanan publik dalam rangka peningkatan kesejahteraan masyarakat. Sesungguhnya permasalahan pelayanan pubik di negara berkembang adalah bagaimana menghilangkan tersumbatnya akses pelayanan publik agar bisa sampai ke akar rumput. Karena itu hanya dapat di lakukan dengan pendekatan kebijakan desentralisasi ( Mc Court, dalam Mark Robinson, 2013 ). Artinya dengan kebijakan desentralisasi sampai ke tingkat pemerintahan desa maka distribusi sumber sumber daya bisa sampai ke akar rumput melalui program pengentasan kemiskinan.

Berdasarkan pengamatan lapangan terkait dengan kapasitas pemerintahan desa dapat dilihat dari fenomena sehari hari jika mengunjungi kantor desa. Misalnya para pegawai atau perangkat desa datang lebih siang, kepala desa sering tidak berada ditempat, masarakat yang datang ke kantor desa jumlahnya relatif sedikit. Disamping kegiatan yang diurus juga bebannya kecil hanya melayani masyarakat yang memiliki kepentingan urusan KTP, kematian, pernikahan, membuat surat pengantar ke Kecamatan atau ke Kabupaten, dan ke Polres urus kelakuan baik ( SKCK ). Karena itu jam kerja para perangkat desa tidak penuh sebagaimana di kantor pemerintahan misalnya sampai jam 16.00 wib. Tapi di kantor desa jam 10.00 wib suasananya sudah sepi dan tempat duduk para pegawainya sudah kosong. Kondisi kantor pemerintahan desa seperti di jelaskan diatas secara umum sudah diketahui masyarakat luas. Fenomena tersebut diatas dapat menjadi justifikasi pernyataan Nurcholis ( 2016 ) bahwa pemerintahan desa sebagai "pemerintahan palsu ". Demikian pula sebenarnya desain pemerintahan desa saat ini “ tidak memiliki memiliki kapasitas yang memadai sesuai beban yang dipikulnya. Apalagi kebijakan pemerintah era Presiden Joko Widodo menggulirkan dana desa sebesar satu milyar rupiah. Dengan dana desa tersebut menambah beban pemerintahan desa semakin bertambah berat. Oleh sebab itu permasalahan yang kompleks di " desa " menarik untuk di teliti mengenai " kapasitas pemerintahan desa " dalam menjalankan tugas dan fungsinya menyelenggarakan pelayanan publik dan program program pembangunan yang di tugaskan oleh pemerintah pusat dan daerah. Meskipun penelitian tentang kapasitas pemerintahan desa telah dilakukan oleh orang lain ( Rosyadi, 2016 ). Namun demikian dengan penelitian ini diharapkan dapat memperkuat temuan kebenaran empiristik penelitian sebelumnya atau penemuan lain yang kemungkinan berbeda.

\section{PERTANYAAN PENELITIAN}

Berdasarkan uraian diatas bahwa melakukan kajian mengenai pemerintahan desa cukup menarik terutama melihat pentingnya peranan desa dalam sistem pemerintahan Indonesia. Akan tetapi dilain pihak kedudukan pemerintahan desa sebagai subordinasi pemerintahan diatasnya masih diperdebatkan oleh pakar administrasi negara seperti yang di jelaskan di atas. Untuk mendalami lebih jauh pertanyaan penelitian yang diajukan yaitu " Bagaimana kapasitas pemerintahan desa dalam menjalankan penyalenggaraan pelayanan publik guna meningkatkan ksejahteraan masyarakat desa. Dengan kata lain apakah "kapasitas pelayanan publik" pada pemerintahan desa mampu mngatasi problem kemiskinan di pedesaan.

\section{KONSEP DAN TEORI}

Dalam konteks penelitian mengenai kapasitas pelayanan publik pemerintahan desa terdapat tiga kata kunci sebagai landasan teorinya yaitu; kapasitas, pelayanan publik dan pemerintahan desa. Jika dalam pembahasan hasil penelitian didukung landasan teori tersebut maka 
memperkuat ketajaman analisis berbasis teori guna mencari kebenaran empirisnya. Secara umum pengertian menengenai "kapasitas yaitu kemampuan menerima beban tertentu. Terminology " kapasitas berasal dari bahasa inggris yaitu " capacity". Istilah tersebut meminjam terminology dari ilmu teknik. Menurut Stevenson ( 2000, p 712 ) mengatakan bahwa “ kapasitas adalah beban maksimal yang dapat ditangani oleh sebuah unit produksi. Dikatakan selanjutnya "capacity is the ability to receive, hold. or absorb". Dengan demikian kapasitas dalam konteks pemerintahan desa yaitu potensi yang digunakan untuk menjalankan tugas dan fungsi penyelenggaraan pelayanan publik. Kapasitas pemerintahan desa mulai dari organisasinya, perangkat desa serta suberdaya lainnya menerima beban tugas dan fungsi sesuai yang ditangani. Dalam konteks kapasitas organisasi Horton dkk dalam Rosyadi (2016) dikatakan bahwa " kapasitas organisasi adalah potensi atau kemampuan organisasi untuk menggunakan keahlian dan sumberdaya yang dimilikinya secara baik guna mewujudkan tujuan tujuannya dan memuaskan harapan dari para pemangku kepentingannya. Pengertian tersebut dimaksudkan yaitu " kapasitas organisasi pemerintahan sebagai bagian dari variabel yang diteliti. Mengenai lemahnya “ kapasitas pemerintahan desa menururt Salahudin dkk selaku editor ( 2016 ) mengutip hasil kajian Pusat Kajian Kinerja Otonomi Daerah (PKKOD) menjelaskan bahwa pertama; belum semua pemerintah desa menyusun dokumen dokumen perencanaan , kedua; pelaksanaan manajemen keuangan dan kekayaan desa belum terslenggara dengan baik, ketiga kapasitas aparatur desa dalam menyusun kebijakan desa sangat lemah, keempat; buruknya kepemimpinan kepala desa dalam penyelenggaraan pemerintahan desa. Keempat dimensi kapasitas pemerintahan desa tersebut diatas merupakan faktor strategis dalam menentukan keberhasilan pelayanan publik dalam penyelenggaraan pemerintahan desa yaitu dimensi perencanaan, administrasi desa, tatakelola keuangan dan kepemimpinan. Demikian pula dikatakan Rosyadi ( 2016 ) lemahnya kapasitas pemerintah desa dapat dilihat dari kemampuannya untuk menyusun data profil potensi desa. Selanjutnya dijelaskan dampak lemahnya kapasitas pemerintahan, hasil riset LPPM IPB menemukan bahwa kajian terhadap 150 dokumen RPJMDes terbukti 80 \% hanya copy paste dari desa lain". Adapun Horton dkk dalam Rosyadi (2016 ) membagi dimensi kapasitas pemerintahan desa yaitu; sumber daya yang terdiri dari perangkat desa, infrastruktur teknologi, sumberdaya keuangan dan manajemen yang terdiri dari kepemimpinan strategis Kepla Desa, manajemen dan proses dan jejaring \& Kaitan. Salahudin dkk ( 2016 ) dari hasil penelitiannya menyimpulkan bahwa untuk mengatasi masalah rendahnya kapasitas pemerintahan desa yaitu " disarankan kepada pemerintah agar menerapkan konsep EGovernment" dalam penyelenggaraan pemerintahan desa. Penguatan kapasitas pemerintahan desa ke depan suatu keniscayaan pemerintahan desa harus mampu menyesuaikan diri dengan perubahan sosial yang sangat cepat. Untuk itu suka atau tidak suka penggunaan teknologi informasi seperti internet, menjadi prioritas utama. Sebab era E- government sudah mulai berjalan dalam penyelenggaraan pemerintahan di Indonesia. Akan tetapi permasalahan klasik mengembangkan teknologi informasi di negara berkembang selalu dikaitkan dengan kondisi infrastruktur, sumberdaya manusia ( SDM ) dan finansial yang belum memadai. Kondisi geografis serta topografi Indonesia memberikan tantangan ekstra dalam upaya memaksimalkan pemanfaatan teknologi informasi di daerah daerah tertentu terutama wilayah pedesaan. Apalagi Indonesia memiliki 73.000 desa dan 8000 kelurahan ( Rosyadi ( 2016 ). Pemerintahan desa meskipun "masih bernasib tragis" ( Suryo,2010), " pemerintahan palsu" atau pseudo government" namun dengan kelebihan dan kekurangannya pemerintahan desa merupakan sub sistem dari sistem pemerintahan Indonesia. Seperti diketahui bahwa fungsi utama pemerintah yaitu menyediakan dan menyelenggarakan " pelayanan publik" dalam rangka mewujudkan kesejahteraan rakyat dan pengentasan kemiskinan.

Sesuai hasil observasi lapangan di kantor desa menemukan "fenomena" bahwa kegiatan 
sehari hari para pegawai kantor desa melayani masyarakat hanya urusan membuat surat pengantar yang harus diteken kepala desa untuk urusan yang menjadi kewenangan instansi pemerintah diatasnya. Oleh sebab itu terbatasnya kewenangan Kepala Desa yang hanya ururusan teken dan stempel surat, maka kegiatan pemerintahan desa dapat diselesaikan hanya sampai jam 11 wib, setelah itu kantor desa sepi. Karena itu Nurcholis ( 2016 ) seperti yang telah dijelaskan diatas menyatakan " pemerintahan desa sebagai pemerintahan palsu" dan tidak ada pelayanan publik" di desa. Pelayanan publik yang dimaksud yaitu "pelayanan dasar" misalnya; bidang kesehatan, pendidikan dan pelayanan kesejahteraan rakyat. Lembaga desa tidak menyediakan dan menyelenggarakan jenis pelayanan publik tersebut, Karena itu masyarakat jika memerlukan pelayanan kesehatan harus pergi ke Puskesmas di wilayah Kecamatan yang letaknya jauh dari tempat tinggal.di desanya. Pemerintahan desa hanya menyediakan "Posiandu". Demikian pula pelayanan pendidikan harus pergi ke kantor Dinas pendidikan yang letaknya di wilayah Kabupaten.

Seperti diketahui di Indonesia penyelenggaraan pelayanan publik menjadi isu kebijakan yang semakin strategis karena perbaikan pelayanan publik di negeri ini berjalan di tempat ( Abdul Mahsyar, 2011 ). Karena itu kebijakan kebijakan pemerintah yang berkaitan dengan pelayanan publik harus terus dikaji dan ditinjau ulang serta perlu ditingkatkan kualitasnya melalui analisis kebijakan yang tepat. ( Istianto, 2011 ). Kebijakan pemerintah harus selalu berorientasi terhadap pelayanan publik yang adil dan merata kepada setiap warga negaranya. Terutama yang menyangkut kebutuhan dasar seperti; sandang, pangan, papan, kesehatan, pendidikan, energy, transportasi, sumber daya air dan akses informasi dan lain lain ( Istianto, 2015 ).

Banyak penelitian mengenai kapasitas pelayanan publik ( public service capacity ) menemukan bahwa "kapasitas pelayanan publik pemerintahan desa" masih lemah dan belum memadai menerima tugas dan fungsi melaksanakan program program pemerintah pusat termasuk dana desa. Beberapa teori yang dikemukakan para pakar mengenai kapasitas pelayanan publik misalnya; Painter ( 2000 ), Grindle and Hilderbrand, 1995; 445 ), Farazmand 2009 ), Lopes and Theisohn 2003;4044 ), Grindleand Hilderbrand 1997; Nunberg 1996 ) dalam Lina Vyas, and Chan Su Jung, and Ahmed Shafiqul Huque, 2013 ). Painter ( 2000 ) menjelaskan " The bulding blocks of effective or good capacity can be divided into three aspects; state, policy and administrative". Selanjutnya dikatakan "The first two capacity involve not only the government but also the social and economic power". Administrative capacity. However, refers to the efficient management of the human and physical resources required for delivering the outputs of government". Sedangkan Grindle and Hilderbrand, 1995; 445 ) mengatakan "The concept of public service capacity can be understood as the combination of both professional knowledge and delivery system with the ability to perform appropriate tasks effectively, efficiently, and sustainably". Selanjutnya Farazmand, 2009 ) juga menjelaskan "No government would survive the day with a broken institutional and legitimacy capacity in public service and administration is imperative ". Kemudian Farazmand mengatakan "Building public service capacity has been discussed widely in studies on public administration and development. Public service capacity can be categorized into three levels. The first and basic level is the individual level capacity, where skills and knowledge are imparted for the primary purpose of fulfilling job requirements and duties. The second is institutional level capacity. The third is related to the whole society. At this level all segmens of the citizens who subscribe to various values are brought together therough networking and cohesion. Hal senada juga di kemukakan serta dipertegas oleh Lopes and Theison, 2003;4044 ) yang mengatakan " public service capacity can help coordinate and allocate resouces by considering the interdependent relationships between groups. All levels are equally important and mutually interdependent". Selanjutnya pakar 
lain menjelaskan mengenai kapasitas pelayanan public yaitu; Grindle and Hilderbrand, 1997; Nunberg 1996 ) menambahkan "Taks of building public service capacity are determined by the necessity, history, or situation in specific contexts.

Berdasarkan pendapat para pakar tersebut diatas yang menjelaskan mengenai " kapasitas pelayanan paublik dapat disimpulkan bahwa membahas mngenai " kapasitas pelayanan publik sangat kompleks. Peningkatan kapasitas pelayanan publik melibatkan seluruh aspek aspek yang saling berkaitan dan saling bergantung. Seperti misalnya; peranan negara, kebijakan, alokasi sumber sumber daya. Penguatan Kelembagaannya, kekuatan sosial - ekonomi. Serta kemampuan dan pengetahuan serta skill aparatur pelaksana. Berdasarkan hasil penelitian diatas lemahnya " kapasitas pelayanan publik " pada pemerintahan desa di pengaruhi oleh beberapa faktor. Seperti misalnya; faktor kemampuan dan skill aparatur pelaksana ( Rosyadi, 2016 ), infrastruktur informasi ( Salahudin, 2016 ), lemahnya kelembagaan dan kedudukan pemerintahan desa sehingga seperti pseaudo government ( Nurcholis, 2016 ). Dengan demikian “ rendahnya kapasitas pelayanan publik pemerintahan desa " berkorelasi kuat terhadap kegagalan pemerintah dalam melaksanakan pembangunan di pedesaan dalam upaya mengentaskan kemiskinan masyarakat yang tinggal di pedesaan. Konstruksi teori tersebut dapat menjadi " hipotesa " dalam penelitian ini untuk dibuktikan kebenaranya secara empiristik di lapangan.

\section{METODE PENELITIAN}

Dalam penelitian ini menggunakan metode penelitian kualitatif. Teknik pengumpulan data dilakukan melalui metode observasi dan didiukung wawancara mendalam atau indepth interview dengan para key informan yang kompeten. Memilih key informan ditetapkaan berdasarkan kriteria informan kunci seperti kepala desa, tokoh masyarakat serta informan lain yang mengerti mengenai pemerintahan desa, otonomi daerah serta informasi lain yang terkait. Adapun teknik analisis menggunakan analisis diskriptif.

\section{ANALISIS HASIL PENELITIAN}

Lokasi penelitian ini di desa Cibuntu Kecamatan Cibitung Kabupaten Bekasi Propinsi Jawa Barat. Desa tersebut letaknya di lingkungan kawasan industri Jababbeka. Bahkan berdampingan dengan kawasan industri tersebut. Dilihat dari letak desa Cibuntu berada pada lingkungan infrastruktur jalan yang startegis. Kurang lebih satu (1) kilometer terbentang jalan Tol Jakarta- Cikampek. Dengan letak geografis Desa Cibuntu potensial sebagai Desa Mandiri. Adapun data dan informasi mengenai desa Cibuntu di uraikan sebagai berikut dibawah ini.

\section{A. GAMBARAN UMUM DESA CIBUNTU KECAMATAN CIBITUNG KABUPATEN BEKASI}

1. Luas Wilayah desa ; 559,66 ha

2. Batas wilayah desa ; Timur ; Ganda Sari timur dan Ganda Mekar Timur, selatan ; Mekar wangi, barat; Lambang Jaya dan utara; Wanasari.

3. Jumlah Penduduk; 23. 197 orang
a. Laki laki ; 11,744 orang
b. Perempuan ; 11.453 orang
c. Jumlah KK ; $7.547 \mathrm{kk}$

4. Mata pencaharian penduduk;
a. Petani; 2.286
b. Pedagang ; 395
c. PNS ; 210
d. Swasta ;3. 355
e. Lain lain;
- TNI/ Polri ; 37
- Pemulung; 68
- Jasa ; 107
- Pertukangan; 188

5. Data potensi desa;
a. Luas sawah; 5 ha
b. Luas perkebunan; 304 ha
c. Luas tanah negara; 35 ha
d. Jumlah binatang;
- Sapi ; 30 ekor
- Kerbau ; 10 ekor
- Kambing; 150 ekor
- Ayam; 20.000 ekor
- Itik ; 5000 ekor

e. Jalan desa; $12 \mathrm{~km}$

f. Jalan kabupaten; $2 \mathrm{~km}$

g. Jalan propinsi ; $5 \mathrm{~km}$ 


\section{Struktur pemerintahan desa}

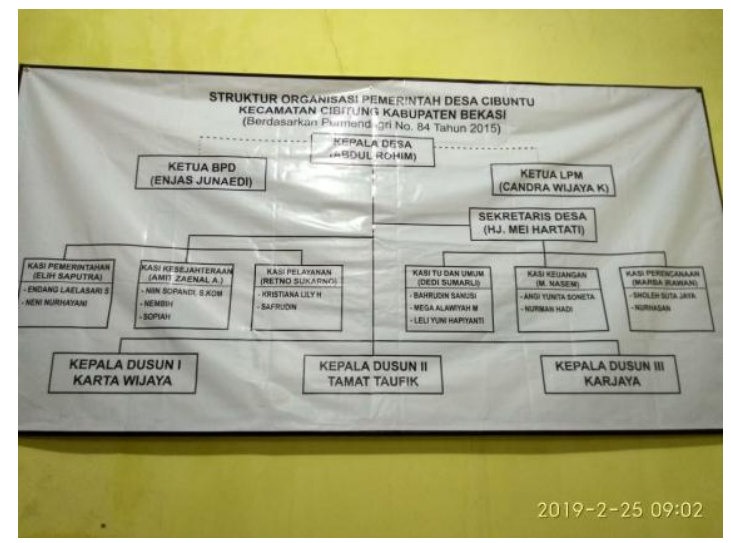

Sumber Operasion Room Kantor Desa Cibuntu

\section{Peta desa}

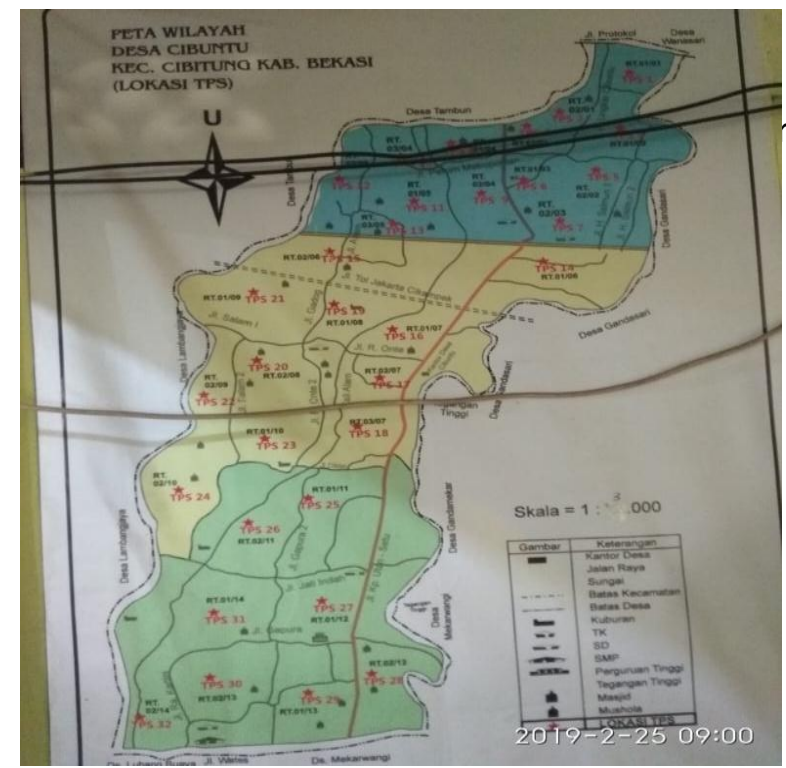

Desa Cibuntu

\section{B. INFORMASI TENTANG PENYELENGGARAAN PEMERINTAHAN DESA}

1. Jumlah pegawai kantor desa; 22 orang

2. Pendidikan ; sarjana ; 1 orang, SLTA ; 15 orang SLTP ; 4 dan SD; 2

3. Tugas dan fungsi Perangkat Desa

a. Kaur Pemerintahan

- Melaksanakan kegiatan dalam hal; kependudukan, pembinaan Rt/ Rw

Keamanan, Hansip, pertanahan, kematian, kelahiran, nikah sipil

b. Kaur Ekbang

- Melaksanakan kegiatan dalam hal; pembangunan jalan, saluran, penagihan PBB, pembangunan rumah tinggal, Usaha

Umkm,domisili usaha.

c. Kaur Kesra

- Melaksanakan kegiatan dalam hal; 1) menyiapkan surat pengantar nikah, N2, N2 dan N3 2) surat domisili yayasan, pendidikan, haji,3). Pembinaan Posyiandu, Karang Taruna, 4). Pulahta masjid, mushola, majelis taklim, kesehtan masyarakat, data anak yatim, orang miskin, zakat, fitrah, dan orang tidak mampu.

d. Kaur Keuangan; mencatat anggaran desa dan mengelola dana desa

4. Urusan yang diperlukan oleh warga setiap hari yaitu;

- Surat pengantar KK, KTP, SKCK, surat kenal lahir, surat kematian, nikah, pengurusan surat tanah, surat tidak sengketa, domisli usaha, haji dll.

5. Jumlah warga yang berkunjung ke kantor desa setiap hari yaitu; kurang lebih 10 orang sampai 15 orang.

6. Sumber keuangan desa terdiri dari;

- Hasil dari tanah kas desa ( TKD ) yang diberikan dari pemerintah Kabupaten

- luran masyarakat melalui dana APPKD

- Bantuan APBD jika anggarkan oleh Pemkab

7. Mekanisme pengelolaan keuangan desa; melalui mekanisme rapat Musyawarah Desa yang diprakasai oleh LKMD dan LMD

8. Pengelolaan dana desa;

- Dalam tahun 2018 dana desa yang di kelola yaitu 860 juta, digunakan untuk membangun jalan desa, embung desa. Saluran air dan prasarana lainnya. Mekanisme penggunaaan dana melalui musyawarah desa yang dihadiri perangkat desa, kepala dusun,ketua RW dan RT , LKMD dan LMD membahas dan memutuskan alokasi dana desa untuk membangun terutama infrastruktur yang mendesak untuk dibangun.

\section{Hasil indepth interview}

Penggalian informasi melalui indepth terkait dengan kapasitas pelayanan publik pada pemerintahan desa meliputi beberapa aspek yaitu; kompetensi aparatur pelaksana, efektifitas 
organisasi pemerintahan desa, kepemimpinan kepala desa dan pengeolaan sumber susmber daya pemerintahan desa. Adapun pendalaman informasi terhadap beberapa aspek diatas kepada informan kunci yaitu Kepala desa, Kaur pemerintahan dan sekretaris desa serta tokoh masyarakat yaitu sebagai berikut;

1. Kondisi dan keadaan perangkat desa dalam melaksanakan kegiatan rutin ;

Ketika di sampaikan pertanyaan kepada Kepala Desa bagaimana kompetensi aparatur pada pemerintah desa?

" sebenarnya kondisi sumberdaya manusia( SDM ) yang ada masih terbatas sebagian besar lulusan SLTA, ada yang SLTP dan SD. Jika untuk mengurus kegiatan rutin sehari hari bisa diselesaikan karena kegiatan administrasi. Akan tetapi urusan yang lebih penting seperti penyusunan anggaran dan perencanaan dan pengelolaan keuangan desa masih sangat lemah".

2. Uapaya untuk memeperbaiki kelemahan tersebut; " untuk mengatasi kelemahan kompetensi perangkat desa saya memang sudah mendesak untuk ditingkatkan kualitasnya dengan mengikuti pelatihan yang diselenggarakan pemkab. Tetapi program bimtek tidak selalu ada ketika dibutuhkan.

3. Kendala kendala dalam penyelenggaraan pemerintahan; Ketika ditanyakan kepada salah seorang kepala urusan bagaimana masalah yang dihadapi aparatur desa dalam memberikan pelayanan publik; diperoleh informasi

" bahwa para aparatur dalam memberikan pelayanan kepada masyarakat yang datang ke kantor desa berbagai macam urusan dapat diselesaikan sesuai dengan yang diminta. Karena urusan yang dikerjakan sehari hari hanya bersifat administrasi seusuai tupoksinya masing masing relatif tidak ada kesulita, yang berarti, karena disamping rutinitas dan yang dilayani setiap hari rata rata 10 sampai 15 orang. Jadi mengerjakan urusan layanan masyarakat pada jam 10.00 Wib sudah selesai.

4. Efektifitas organisasi dalam penyelenggaraan pemerintahan;
Ketika ditanyakan Sekretaris Desa apakah para aparatur desa memahami tupoksi masing masing; di peroleh informasi.

" pada prinsipnya seluruh perangkat desa sesuai dengan tupoksinya masing masing mampu mejalankan dengan cukup baik dalam melayani masyarakat yang datang di kantor desa" setiap hari". Apakah dalam memberikan pelayanan tersebut ada hal yang tidak terselesaikan?. Seluruh keperluan masyarakat secara umum dapat diselesaikan hari itu juga. Kcuali urusan yang memerlukan waktu bebeapa hari misalnya urusan KTP, sertifikat tanah, AJB, karena penyelesaiannya berada pada instansi Kabupaten yaitu di SKPD". Ketika ditanyakan jumlah aparatur desa sebanyak 22 orang ? sebenarnya secara umum perangkat desa jumlahnya 16 orang tapi karena Desa Cibuntu wilayahnya luas memerlukan tenaga untuk mengerjakan kegiatan laangan. Apa yang sering menjadi keluhan masyarakat dalam hal urusan pelayanan di kantor desa?, sebagian besar masyarakat mengeluh mengenai urusan KTP.

5. Aspek kepemimpinan kepala desa

" ketika ditanyakan kepada informan yang terpilih yaitu "tokoh masyarakat" menegnai bagaimana kepemimpinan kepala desa saat ini? Mendapat informasi; " Oleh sebab itu ketika mencalonkan kembali untuk periode berikutnya " terpilih kembali untuk masa bakti berikutnya. Artinya gaya kepemimpinan komunikatif dan turun kebawah" dengan gaya kepemimpinannya" disukai oleh rakyatnya.

6. Aspek pembangunan wilayah desa

" ketika ditanyakan mengenenai program pmbangunan di desa kepqda kepala desa menjelaskan bahwa pada tahun yang lalu dan sebelumnya mendapat dana desa sebesar 800 juta diperuntukan untuk pembangunan jalan desa, irigasi, saluran air dan lainnya. 
Berdasarkan data dan informasi yang telah didiskripsikan diatas data dan informasi yang telah dikumpulkan melalui obervasi, grounded research dan indepth interview dapatdi intreprestasikan sbagai berikut;

1. Desa Cibuntu sebagai lokasi penelitian secara geografis letaknya berada di wilayah kota kabupaten serta berada ditengah kawasan industry Jababeka. Karena itu Desa Cibuntu termasuk desa perkotaan. Ciri desa perkotaan mata pencaharian penduduk jumlah petani lebih sedikit disbanding di luar petanian.

2. Wilayah desa Cibitung semula tanah sawah sangat luas tinggal 5 ha, karena itu penduduk yang mata pencahariannya sebagai petani hanya $10 \%$ yaitu sejumal 2.286 orang dari jumlah penduduk yaitu sejumlah 23.197 orang.

3. Kegiatan pemerintahan desa hanya bersifat urusan administrasi pembuatan surat pengantar untuk urusan pembuatan KTP, akte kelahiran, dan urusan lain yang diteruskan ke instansi pemerintah di Kabupaten. Karena itu kegiatan pemerintahan praktis jam 11 wib para pegawai kantorn desa sudah tidak berada ditempat.

4. Perangkat desa rata pendidikanya relatif rendah yaitu SLTA dan SLTP serta SD, tp di desa Cibuntu 1 ora sarjana. Karena itu para pegawai kurang memiliki pengetahuan dan ketrampilan mengenai tatakelola keuangan desa, menyusun anggaran, perenaan program dan laporan program dan keuangan. Oleh sebab itu dalam mengelola dana desa banyak mengalami kendala.

5. Kepemimpianan kepala desa dinilai masyarakat komunikarif dan mau turun kebwah.

\section{KESIMPULAN}

Berdasarkan pembahasan hasil peneltian mengenai " kapasitas pelayanan publik pada pemerintahan desa dengan menggunakan teknik pengumpulan berdasarkan observasi, grounded research dan indepth interview, dapat disusun kesimpulan sebagai berikut;

1. Kebijakan desentralisasi sampai ke pemerintahan desa sebenarnya merupakan cara yang efektif melaksanakan distribusi sumber sumber daya sampai ke akar rumput.

2. Pemerintahan desa dalam kegiatan sehari hari hanya memberikan palayanan urusan yang relatif kecil seperti membuat surat pengantar untuk instansi pemerintah diatas sesuai kewenangannya.

3. Sedangkan pelayanan dasar seperti pendidikan, kesehatan dan pelayanan kesejahteraan serta pangan papan, air bersih, transportasi, tidak ada kewenangan pada pemerintahan desa. Karena itu disebut " pemerintahan palsu".

4. Pada hakekatnya lembaga desa sangat potensial mendudkung program pembangunan dalam mengatasi kemiskinan di desa jika diberi penguatan kelembagaanya baik teknis dan administratif.

5. Kapasitas pelayanan publik pemerintahan desa belum mampu untuk menerima beban progam pembangunan seperti dana desa karena para aparatur tidak memiliki pengetahuan teknis penyusunan anggaran, perenanaan program, laporan keuangan. Serta melaksanakan tugas secara tepat dan efektif.

6. Para aparatur perangkat desa faktanya pendidikannya masih relatif rendah. 
VII. SARAN

1. Peningkatan kualitas SDM perangkat desa melalui pelatihan dan bimtek mengenai tatakelola anggaran dan penyusunan perencanaan.

2. Penempatan wajib "tenaga terampil administrasi pemerintahan desa tingkat menengah.

\section{DAFTAR PUSTAKA}

Abdul Mahsyar, 2011, Masalah Pelayanan Publik di Indonesia Dalam Perspektif Administrasi Publik, vol 1, no. 2, oktober 2011

Istianto, Bambang, 2011, Manajemen Pemerintahan Dalam Perspektif Pelayanan Publik,

Penerbit Mitra Wacana Media, Jakata

Istianto, Bambang, 2015, Gaya Manajemen Bisnis VS Peranan Negara Kuat Dalam Mengurus Negara, Penerbit, PT. Mitra Wacana Media, Jakarta

Nurcholis. 2016, Desa Dinas, Penerbit Bee Media Pustaka Jakarta

Mark Robinson, 2013, From Old Public Administration to the New Public Service, Implication For Public Sector Reform in Developing Countries, Publiser Global

Centre For Public Service, GCPSE, UNDP

Lina Vyas, Jung, Ahmed Shafiqul Huque, 2013, Challenges for Public service Capacity and the Role of Public Employee Training as a Moderator in India. In Public

Management Review, Nopember 2013

Rosyadi, Slamet,2016, Pengembangan Kapasitas Pemerintahan Desa, Penerbit PT. Raja

Grafindo, Jakarta

Suryokoco Suryoputro, Peningkatan Kapasitas Pemerintah Desa,

https//suryokocolink.wordpress.com

Salahudin, 2016 Model Penguatan

Kapasitas Pemerintah Desa Dalam
Menjalankan Fungsi Pemerintahan

Berbasis ( E- Government ) Menuju

Pembangunan Ber-

Daya Saing, Penerbit DPPM Universitas Muhamadiyah Malang

Stevenson, J. William, 2019, Operations Management, edisi 7, The Macgraw- Hill Series $\ln$

Operations and Decisions Sciences. 